\title{
Fanowskie praktyki autorskie Rewolucja autorstwa zbiorowego
}

\author{
Fan's Authorial Rractices
}

The Subversion of Collaborative Authorship

\begin{abstract}
Streszczenie: Artykuł analizuje dotychczasowe ujęcia autorstwa w badaniach nad fandomem. Następnie skupia się na autorstwie w ramach twórczości fanowskiej. Rozpoznaje tutaj zbiorowy i intertekstualny wymiar fanowskiego autorstwa, który uznać można za model alternatywny wobec dominującego rynkowego określania autorstwa jako samotnej praktyki prowadzącej do powstania unikatowego tekstu. W efekcie podważona zostaje dominująca pozycja tak ustrukturowanego autorstwa. Ujawniony zostaje także subwersywny potencjał fanowskich praktyk twórczych jako umożliwiających przeformułowanie postromantycznego autorstwa i opartego na nim ekspansywnego prawa autorskiego.
\end{abstract}

Słowa kluczowe: autorstwo, autor, produkcja kulturowa, fanfiction, prawo autorskie, twórczość zależna, twórczość transformacyjna

\section{Refleksja na temat autorstwa w badaniach nad fandomem (zarys kontekstów)}

Wątek autorstwa w badaniach nad praktykami fanowskimi i zaangażowanym odbiorem najczęściej pojawia się w kontekście pozycji twórcy tekstu wyjściowego, wokół którego tworzy się dana wspólnota fanowska. Status autora tekstu popkulturowego określić można jako ambiwalentny: z jednej strony twórczość fanowska realizuje zasadę wielości interpretacji postulowaną przez Rolanda Barthesa w jego słynnym eseju z 1968 roku - Śmierć autora; z drugiej strony 
jednak fandom nieustannie odwołuje się do kanonu ${ }^{1}$ popkulturowego tekstu. Marta Tymińska i Agata Włodarczyk streszczają sytuację popkulturowego autora w swoim tekście Fan Fiction a literacka rewolucja fanowska. Próba charakterystyki zjawiska w następujący sposób: „Choć więc stracili oni [autorzy] panowanie nad swoimi tworami, wciąż zachowują status wszechwiedzących wyroczni”'. Znamienne jest przy tym, że badaczki przywołują postać Jossa Whedona jako przykład autora stawianego przez fanów na piedestale. Jest on scenarzystą i reżyserem, który w ostatnich latach znacząco stracił na popularności wśród dawnych zagorzałych odbiorców, a narastająca krytyka zmusiła go już w 2013 roku do wycofania się z mediów społecznościowych. Obrazuje to, że kultowy status autora $\mathrm{w}$ fandomie jest nie tylko ambiwalentny, ale również przejściowy i niezwykle szybko może zmienić się z adoracji w potępienie ${ }^{3}$. Zagadnienie funkcjonowania autora tekstu wyjściowego $\mathrm{w}$ fandomie czy też generalnie stosunku fanów do autorstwa analizuje również Barbara KuleszaGulczyńska, która pisze w Czym różni się autor od aŁtora, czyli fanowskie gry $z$ autorstwem:

[...] przyjęcie roli kłusownika nie zakłada jednak podważenia pozycji władcy. I rzeczywiście, kwestionując prawo autora do jego tekstowego terytorium, fani nie zaprzeczają jego fundamentalnej roli twórczej, paradoksalnie uznając niejako jego tradycyjną wyższość [...] Z jednej strony fani, ośmieleni przez tendencje i zjawiska z zakresu kultury remiksu czy kultury uczestnictwa, jednoznacznie kwestionują decydującą rolę konkretnego autora w kształtowaniu znaczeń tekstu i ostateczny charakter autorskich wypowiedzi dotyczących konkretnych elementów świata przedstawionego. Z drugiej jednak - autor, rozumiany jako synonim pisarza, czyli w uproszczeniu osoby, która profesjonalnie zajmuje się pisarstwem i ma na koncie publikacje drukowane (!), to wciąż dla większości z nich pozytywny punkt odniesienia, a także określenie nobi-

1 Terminu kanon używam tutaj w znaczeniu obowiązującym we wspólnotach fanowskich, czyli tak, jak zdefiniowałam go wraz z Joanną Krzyżanowską na potrzeby Stownika fandomu i fanfiction, jako całokształt treści zawartych w danym popkulturowym tytule, wraz z wypowiedziami twórców na temat tego tytułu. Zob. A. Kobus, J. Krzyżanowska, Słownikfandomu i fanfiction [w:] Netlor. Wiedza cyfrowych tubylców, pod red. P. Grochowskiego, Torun 2012, s. 301-359.

2 M. Tymińska, A. Włodarczyk, Fan Fiction a literacka rewolucja fanowska. Próba charakterystyki zjawiska w następujący sposób, „Panoprikum” 2012, nr 11 (18), s. 99.

3 Więcej o relacjach między twórcami popkultury a fankami, zob. A. Kobus, Burzenie czwartej ściany. Strategie budowania relacji twórców popkultury z fankami, [w:] Seriale w kontekście kulturowym. Widzowie - fani - twórcy, pod red. A. Krawczyk-Łaskarzewska, A. Naruszewicz -Duchlińska, Olsztyn 2016. 
litujące, szczególnie podczas dyskusji toczących się wokół ich własnej, fanowskiej twórczości ${ }^{4}$.

Kulesza-Gulczyńska zwraca więc uwagę na nobilitujący charakter autorstwa w kulturze mainstreamowej, który rzutuje na odbieranie pozycji autora popkulturowego tekstu w fandomie. Uważny badacz popkultury zwróci tutaj uwagę - jak uczyniły to Tymińska i Włodarczyk - na fakt, że popkulturowa produkcja odbywa się najczęściej w modelu autorstwa zbiorowego ${ }^{5}$, a finalny produkt tekst, wokół którego gromadzi się fandom - jest efektem działania i negocjacji wielu zaangażowanych osób, sił i wpływów, rzadko stanowi akt twórczej ekspresji, nie wpisuje się więc w „tradycyjny model autorstwa”, wspomniany przez KuleszęGulczyńską. W ten sposób znaczący status autora w kulturze fanowskiej nabiera charakteru specyficznego fantazmatu, społecznej fantazji na temat charakteru autorstwa, który nie ma wiele wspólnego z mechanizmami produkcji kulturowej, czyli praktyką popkulturowej twórczości. Podkreślenie roli autora jako twórcy kanonu odczytać można jako swoista tęsknotę za autorstwem w sytuacji, gdy popkulturowy obiekt afektywnego (fanowskiego) przywiązania pozbawiony jest jasno określonego (osobowego) źródła, czyli nie wpisuje się w tradycyjny, czy wręcz romantyczny model autorstwa ${ }^{6}$. Jest to interesujący wątek, do którego powrócę w dalszym toku wywodu.

Innym kontekstem, w ramach którego omawia się autorstwo w kulturze fanowskiej, jest właśnie Barthesowski postulat śmierci autora i narodzin czytelnika, czyli odejście od traktowania autora jako gwarancji znaczeń tekstu i zwrócenie się w stronę interpretacyjnego pluralizmu. Prowadzi to prosto do pragmatycznego ujęcia interpretacji w myśli Stanleya Fisha i jego kontynuatorów oraz do zwrócenia uwagi na wielość potencjalnych znaczeń zawartych w każdym tekście, także ze względu na intertekstualny wymiar wszelkiej twórczości. Intencja autorska przestaje być wiążąca i obowiązująca, powstaje szereg interpretacji, które można - lub nie - porządkować hierarchicznie jako mniej lub bardziej wierne temu, co uznane zostaje za „przekaz dzieła”. Twórczość fanowska w tym

4 B. Kulesza-Gulczyńska, Czym różni się autor od aŁtora, czyli fanowskie z autorstwem, „Tekstualia" 2015, nr 2 (41), s. 56.

${ }^{5}$ M. Tymińska, A. Włodarczyk, dz. cyt., s. 100.

6 Zagadnieniu kulturowych wzorców autorstwa w europejskiej kulturze nowożytnej poświęcona jest moja praca doktorska - Modele autorstwa w kulturze Zachodu. Fantazmat podmiotu autorskiego. Analizuję w niej pojawienie się autora jako źródła tekstu i gwarancji jego sensów w kontekście dyskursów estetycznych i politycznych XVIII i XIX wieku oraz w kontekście formowania się komercyjnego rynku literackiego. W niniejszym artykule będę opierała się na wnioskach z tej rozprawy. 
ujęciu dowodzić ma słuszności tezy o wielości znaczeń i traktowana jest przede wszystkim jako świadectwa odbioru. Drugorzędna jest natomiast jej rola jako twórczości właśnie, jako produkcji kulturowej. W tym ujęciu zniwelowany zostaje element autorstwa twórców fanfiction, którzy w pierwszej kolejności stają się odbiorcami. Jest to o tyle znaczące, że odniesienie postulatu śmierci autora do fanowskiej produkcji kulturowej (a więc fanowskiej twórczości) naświetla także podstawowy impas wynikający z propozycji Rolanda Barthesa, a także $\mathrm{z}$ równolegle wyłożonej tezy Michaela Foucaulta, który w eseju Kim jest autor? z 1969 roku pyta wprost: „A co to za różnica, kto mówi?”. Impas wynika z zetknięcia się podważania znaczenia autorskiego głosu - autorskiej interpretacji - z postulatami reprezentacji medialnej i polityki tożsamościowej (identity politics), która podkreśla znaczenie jednostkowego głosu jako unikatowego wkładu w kulturowy dorobek. Biorąc pod uwagę, że znaczna część badań nad fandomem ufundowana jest na dorobku studiów kulturowych z okręgu Centre for Contemporary Cultural Studies (CCCS) - dla których zagadnienia rasy, klasy, płci i orientacji stanowią podstawowe kategorie badawcze - bezrefleksyjne przyjęcie teorii śmierci autora (traktowane współcześnie jako intelektualna klisza) prowadzi do poważnych problemów metodologicznych w obrębie fantropologii. Jeśli autorska interpretacja nie ma większego znaczenia niż inne, jeśli autor jest tylko formalną funkcją tekstu', jakie znaczenie ma to, że dany tekst fanowski powstał w wyniku działań kobiety lub mężczyzny, nastolatka czy osoby dorosłej, białej czy czarnoskórej, heteroseksualnej czy queerowej? Jakie znaczenie ma, kto mówi? Warto podkreślić jednak, że impas wynika tutaj nie tyle z chęci odrzucenia postmodernistycznej dekonstrukcji autorstwa jako gwarancji znaczenia, ale właśnie z chęci zachowania dorobku Barthesa, Focaulta i ich następców (zachowania prawa do pluralizmu interpretacyjnego), przy jednoczesnej możliwości identyfikacji specyfiki danego autorskiego głosu jako wypowiedzi wyłaniającej się z konkretnego miejsca w kulturze: wypowiedzi kobiecej, feministycznej, queerowej i tak dalej.

Szeregu propozycji wyjścia z tej sytuacji dostarcza krytyka feministyczna, dla której kwestia autorstwa kobiecego stanowi jedno z kluczowych zagadnień. Szczególnie interesująca w kontekście fan studies jest propozycja Sary Ahmed zawarta w Differences That Matter. Feminist Theory and Postmodernism. Badaczka zauważa, wychodząc zresztą wprost od Śmierci autora Barthesa, że autor może zachować pewną pozycję, nie jako gwarancja znaczeń tekstu, ale jako wyznacznik

7 M. Foucault, Kim jest autor?, [w:] tegoż, Powiedziane, napisane. Szaleństwo i literatura, tłum. B. Banasiak, Warszawa 1999, s. 200.

8 Tamże, s. 212. 
społecznej pozycji tekstu, jako jego kontekst wskazujący na sytuowanie się danego tekstu w ramach formacji dyskursywnych i inherentnych dla nich relacji władzy ${ }^{9}$.

Wspominając krytykę feministyczną, warto zawrócić uwagę na jeszcze jeden popularny kontekst analizy autorstwa w fandomie, czyli na funkcjonowanie fanworks jako twórczości kobiecej. Daje się bowiem zauważyć, że postmodernistyczna dekonstrukcja autorstwa jest wyraźnie upłciowiona i odnosi się do modelu męskiego autorstwa (uchodzącego za uniwersalny). Wątek ten obecny jest już w pracy Nancy K. Miller - Subject to Change. Reading Feminist Writing (1988), w której badaczka stwierdza wprost, że kryzys autorstwa to kryzys tradycyjnej męskości. Ma dodatkowy sens, jeśli weźmie się pod uwagę, że propozycja śmierci autora została wystosowana przez queerowych mężczyzn (Barthesa i Foucaulta). Również Ahmed zauważa, że kobiecy podmiot autorski nie jest żywy, ponieważ nigdy nie zyskał dyskursywnej obecności; nie jest też jednak martwy, bo nie zajmuje uprzywilejowanej pozycji tradycyjnego autorstwa, które dekonstruuje refleksja postmodernistyczna ${ }^{10}$. Obrazuje to, jak problematyczne jest proste przełożenie postulatów śmierci autora na praktyki twórczości fanowskiej, szczególnie biorąc pod uwagę, że twórczość ta reprezentuje sobą jeden z nielicznych (jeśli nie jedyny) model dominacji kobiecego autorstwa w ramach produkcji kulturowej.

Dodatkowym kontekstem jest tu także nieodpłatny charakter tej produkcji, która z założenia pozbawiona jest możliwości uzyskania wynagrodzenia. Jak wiadomo nieodpłatna praca kobiet stanowi jeden z elementarnych mechanizmów płciowej opresji, a szereg instytucji społecznych (praca domowa czy macierzyństwo) opiera się na wyzysku tejże darmowej pracy ${ }^{11}$. W ten sposób fakt, że zdominowana przez kobiece autorstwo sfera kulturowej produkcji ma nieodpłatny charakter nabiera niepokojącego wydźwięku ${ }^{12}$. Czy w związku ze statystyczną dominacją kobiet/dziewcząt w ramach twórczości fanowskiej można wręcz mówić, że jest to twórczość kobieca? Byłabym ostrożna przy wyciąganiu takiego wniosku, przede wszystkim dlatego, że wciąż niezwykle mało wiemy o mechanizmach i procesie twórczym w obrębie fanowskiej produkcji kulturowej, a badania statystyczne społeczności internetowych są zazwyczaj niepewne i niepełne.

9 S. Ahmed, Differences That Matter. Feminist Theory and Postmodernism, New York 2004, s. 122.

10 Tamże, s. 141.

11 Zob. K. Kielos, Jedyna pteć. O tym, dlaczego prześladuje cię homo oeconomicus i jak niszczy twoje życie, nie mówią już o światowej gospodarce, Warszawa 2014.

12 Daleka jestem od postulowania komercjalizacji twórczości fanowskiej, szczególnie w świetle tego, że właśnie komercjalizacja fanfiction w fandomie Zmierzchu Stephanie Meyer doprowadziła do rozpadu tej formacji jako wielkiego fandomu medialnego. Zob. Fic. Why Fanfiction Is Taking Over the World, pod red. A. Jamison, Dallas 2013. 
Sam wątek autorstwa fanów jako twórców i producentów tekstów kulturowych pojawia się dość rzadko. Obecny jest w znanej już książce Sheenagh Pugh The Demoratic Genre. Fan Fiction in a Literary Contex. Badaczka wprowadza tu podstawowe kategorie związane $\mathrm{z}$ literacką produkcją kulturową $\mathrm{w}$ fandomach: estetyczne zagadnienie oryginalności w przypadku twórczości zależnej, jej modele i mechanizmy („więcej dzieła” lub „więcej z dzieła”, „co jeśli?” i „co jeszcze"), stosunek do kanonu w różnych fandomach i różnice w podejściach między pisarstwem fanowskim a zawodowym. Umiejscawia fanfiction w ramach procesów historycznoliterackich i nadaje tym samym szerszy kontekst omawianemu zjawisku. W książce przytoczone zostają również wypowiedzi fanek na temat tego, czemu podejmują się tego rodzaju twórczości i czy jest ona satysfakcjonująca, skoro nie idzie w parze z żadną finansową rekompensatą i niesie tylko potencjał emocjonalnej gratyfikacji (w zależności od rezonansu, jaki dany fanwork wywoła w odbiorcach). W ten sposób The Democratic Genre funkcjonuje jako najbardziej pogłębiona i wyczerpującą analiza mechanizmów powstania fanfiction w dotychczasowym dorobku prac z zakresu fan studies. Jednak jak zauważa Pugh, jej celem jest bardziej złożona analiza, dzięki której możliwe będzie udzielenie odpowiedzi na pytania: jakiego rodzaju pisarstwo stanowi fanfiction, na jakie potrzeby odpowiada, jaka jest jego geneza i jak się zmieniało na przestrzeni lat ${ }^{13}$. I chociaż w swojej pracy skupia się raczej na twórcach fanfiction niż ich odbiorcach, nie jest to bezpośrednia analiza mechanizmów autorskich $\mathrm{w}$ fanfikach. Jasne jest także, że nie można odpowiedzieć na pytanie o autorstwo fanfiction, nie analizując samej twórczości fanowskiej.

\section{Mechanizmy produkcji kulturowej w fandomach}

Podstawową cechą twórczości fanowskiej jest jej charakter twórczości zależnej. Fanfiction, podobnie jak każdy przejaw fanworks, powstaje w oparciu o inne teksty kultury. Co więcej, twórczość fanowska traktowana być może jako skrajny przejaw inherentnej dla każdego tekstu kultury intertekstualności ${ }^{14}$, w której

13 S. Pugh, The Demoratic Genre. Fan Fiction in a Literary Contex, Glasgow 2005, s. 11.

${ }^{14}$ Używam tu pojęcia intertekstualności w znaczeniu, w jakim termin ten pojawia się w pracy Julii Kristevej Stowo, dialog i powieść z 1969 roku. Intertekstualność nie jest więc świadomym zabiegiem stylistycznym, ale funkcją języka wynikającą z jego intersubiektywnego charakteru i ograniczeń języka jako systemu - za pomocą ograniczonej liczby słów staramy się wypowiedzieć nieograniczoną liczbę myśli, zmuszani tym samym do nieświadomych cytatów i powtórzeń. Nie istnieją więc teksty „własne” (ponieważ język nie należy do nas) ani „oryginalne” w znaczeniu 'niepowtarzalne'. 
tekst zależny nie zostanie w pełni (czy nawet wystarczająco dobrze) zrozumiany bez znajomości tekstu wyjściowego. Pod tym względem fanworks to twórczość niesamodzielna, chociaż oczywiście wewnętrzna różnorodność twórczości fanowskiej sprawia, że zdarzają się wyjątki od tej reguły. Warto także zauważyć, że zbytnie oderwanie od tekstu wyjściowego bywa piętnowane w fandomie: czy to przez uznanie takiego fanfika za „niekanoniczny”, czy też przez stwierdzenie, że jego treść jest zbyt ogólna, a gdyby zmienić bohaterom imiona, zabrakłoby odniesienia do kanonu, na którym ten bazuje.

Niesamodzielność twórczości fanowskiej odnosi się także do ciekawego aspektu jej charakteru twórczości zależnej. Chodzi mianowicie o sytuację, w której fanworks powstaje wbrew albo na przekór intencji zawartej w tekście wyjściowym. Chociaż na poziomie popkultury trudno przypisać tekstowi klarowną intencję autorską ze względu na jej status twórczości zbiorowej właśnie, fanworks funkcjonuje często jako dekonstrukcja w rozumieniu Jacquesa Derridy, czyli rozwinięcie elementarnej niespójności tekstu, skupienie na tym, co ukryte „pomiędzy wierszami”. Już w tym miejscu zaznacza się ciekawe mnożenie poziomów autorstwa: jeśli wyjściowy tekst popkulturowy jest efektem działania autorstwa zbiorowego, tekst zależny stanowi dopisanie kolejnego czynnika czy podmiotu autorskiego. Uważam bowiem, że każdy tekst fanowski posiada, oprócz autora znanego z pseudonimu czy imienia i nazwiska, także współautora w postaci twórców dzieła wyjściowego. Ignorowanie czy przeciwstawianie się zadeklarowanej przez popkulturowych twórców intencji autorskiej sprawia, że fanworks staje się rodzajem współautorstwa mimo woli.

Analizowanie twórczości fanowskiej w kontekście autorstwa zbiorowego nie jest obce refleksji nad fandomem. Wątek ten pojawia się chociażby w klasycznej pracy Fan Fiction and Fan Communities in the Age of the Internet pod redakcja Karen Hellekson i Kristiny Busse (2006). Najczęściej odniesienie do autorstwa zbiorowego $\mathrm{w}$ fandomie następuje przez analizę fanowskiej produkcji kulturowej w modelu prosumpcji, ze wskazaniem zaniku klarowanego podziału na producenta i konsumenta, czy też nadawcę i odbiorcę komunikatu. Fanworks niezwykle klarowanie naświetla fakt, że kulturowa konsumpcja jest niezbędnym elementem napędzającym kulturową produkcję, co stanowi także znaczący argument na rzecz zachowania możliwe szerokiej domeny publicznej jako kulturowego rezerwuaru ${ }^{15}$.

W innym ujęciu wskazuje się także na współautorstwo w obrębie twórczości fanowskiej przez analizę takich instytucji jak beta reading (obiegowo określana

15 O zagrożeniu domeny publicznej we współczesnej kulturze korporacyjnej zob. J. Litman, The Public Domain, [w:] „Emoty Law Journal” 1990, nr 4 (39), s. 965-1024. 
beta) i szereg udostępnianych autorom fanfiction samouczków, mających na celu poprawienie ich warsztatu. Wskazuje to na fakt, że autorstwo w ramach twórczości fanowskiej funkcjonuje jako współautorstwo, a także, że społeczności fanowskie zasadniczo wspierają twórczość swoich członków. Istnienie takich instytucji jak analizatornie sugeruje z kolei nie tylko, że twórczość fanowska, charakteryzująca się rażącymi brakami warsztatowymi, będzie piętnowana przez innych fanów, ale również ilustruje, że nawet dla kiepskiego jakościowo tekstu istnieje rynek zbytu w formie jego analiz. Analizy zresztą również można uznać za mechanizm mnożenia współautorstwa. Bazują one bowiem na fanfiction, czyli tekście zależnym, najczęściej też mają formę dialogiczną (dialogu z tekstem i między analizatorami). Sytuację tę można określić jako współautorstwo trzeciego stopnia, gdzie tekst końcowy w postaci analizy (przytoczonego fragmentu testu fanfiction i wyśmiewającego go dialogu) opiera się na tekście zależnym (współautorstwie drugiego stopnia), który z kolei bazuje na tekście popkulturowym (pierwotne współautorstwo lub autorstwo mnogie, zbiorowe w zależności od przyjętej terminologii).

Biorąc pod uwagę bogactwo form w twórczości fanowskiej i skomplikowane wzajemne odniesienia tekstów, poziomy współautorstwa nie zawsze są tak łatwo rozpoznawalne. Warto jednak zwrócić uwagę na fakt, że chociaż analizatornia wydaje się instytucją restrykcyjną w ramach twórczości fanowskiej (piętnującą, ustanawiającą standardy, deprecjonującą różne formy ekspresji w ramach twórczości fanowskiej, na przykład self-insert i postaci w rodzaju Mary Sue), w rzeczywistości jej funkcjonowanie stanowi powielenie mechanizmów autorstwa fanowskiego oraz dalszą produkcję kulturową w ramach tej twórczości.

Potencjał autorstwa w ramach kultury fanowskiej jako współautorstwa realizuje się w relacji do kanonu i fanonu. Obie te instytucje stanowią teksty wyjściowe dla twórczości zależnej, przy czym fanon to również tekst zależny. Termin fanon oznacza oczywiście 'kanon fanowski, wtórny', zespół motywów zaczerpniętych z fanfiction $\mathrm{w}$ danym fandomie, które rozpowszechniły się do tego stopnia, że oderwały się od konkretnych tekstów i autorów, stając się rodzajem kulturowego zaplecza danej społeczności fanowskiej ${ }^{16}$. Tym samym fanon najpełniej realizuje współautorstwo jako model twórczości fanowskiej oraz prosumpcyjny charakter produkcji kulturowej. To twórczość, której podstawowym zadaniem jest wspomaganie dalszej twórczości i która działa na zasadzie wspólnego i dostępnego wszystkim kapitału kulturowego, podobnie jak domena publiczna. Istnienie fanonu - a więc dzielonego rezerwuaru motywów

${ }_{16}$ Zob. A. Kobus, J. Krzyżanowska, Stownik fandomu i fanfiction [w:] Netlor. Wiedza cyfrowych tubylców, pod red. P. Grochowskiego, Toruń 2012, s. 301-359. 
i elementów pochodzących z popularnych tekstów fanowskich - podkreśla także, że współautorstwo w obrębie kultury fanowskiej odnosi się nie tylko do popkulturowych tekstów wyjściowych, lecz również do tekstów innych fanów, a także, że jako model autorstwa zbiorowego twórczość fanowska jest niekonkurencyjna. Będąc środowiskiem wspomagającym twórczość na instytucjonalnym poziomie i pozwalającym na powszechne wykorzystywanie obiegowych motywów, społeczności fanowskie reprezentują model autorstwa zbiorowego, który nie jest oparty na konkurencji między twórczymi jednostkami. Spory o pierwszeństwo wykorzystania danego motywu czy wyłączność na jego użycie zasadniczo nie pojawiają się w ramach kultury fanowskiej, przynajmniej na poziomie fanfiction. Kontrolowanie odbioru i cyrkulacji tekstów fanowskich odbywa się za pomocą innych mechanizmów: respektowania zakazu repostowania tekstu czy wymaganej zgody na tłumaczenie. Łatwo zauważyć, że środki te służą przede wszystkim umożliwieniu autorom fanfiction wglądu w odbiór ich prac. Jest o tyle istotne, że emocjonalna gratyfikacja, związana właśnie z odbiorem, stanowi ekwiwalent wynagrodzenia. Zapłatą za tekst fanfiction są kudosy i komentarze, możliwość wglądu w reakcje odbiorców na dany tekst. Niekonkurencyjnego charakteru twórczości fanowskiej nie należy również mylić z przyzwoleniem na plagiat. Czym innym jest zaczerpnięcie motywu $\mathrm{z}$ fanonu czy charakterystyki postaci z innego fika (przy wskazaniu źródła w nocie autorskiej lub nawet bez tego aktu kurtuazji), a czym innym podpisanie czyjegoś tekstu swoim nazwiskiem lub pseudonimem. Plagiat to nie zjawisko wykorzystania czyjej twórczości do dalszej (w różnym stopniu) kreatywnej pracy, ale zawłaszczania tekstu jako takiego.

Za potraktowaniem twórczości fanowskiej jako niekonkurencyjnej świadczy także jej repetytywność, której przejawem jest właśnie fanon (powtarzanie popularnych rozwiązań) oraz szereg innych instytucji w rodzaju chociażby: promtu, dzielenia headcanonu, czy nawet prosty fakt, że autorzy fanfiction powtarzają w swojej twórczości podobne rozwiązania w wielu tekstach, a odbiorcy poszukają podobnych motywów w kolejnych utworach. Obowiązujący na popularnych portalach system tagów i oznaczeń zasadniczo umacnia ten stan rzeczy, umożliwiając znajdowanie znaczącej liczby tekstów z upragnionym motywem (pairingiem, rodzajem AU czy nawet kinkiem). Im więcej realizacji danego motywu, tym lepiej - tym paradoksalnie bogatsza staje się twórczość fanowska.

Oczywiście pod wieloma względami repetytywność kultury fanowskiej stanowi proste przeniesie na jej grunt tej cechy kultury popularnej, która oparta jest na powtarzaniu schematów w ramach seryjnej produkcji. Popkultura funkcjonuje jednak w innym systemie autorskim, którego instytucjonalnym zapleczem jest korporacyjne prawo autorskie. W tym obiegu kulturowym wystarczające podobieństwo między tekstami stanowi dostateczny powód do po- 
zwu, co wskazuje na jego konkurencyjne nastawienie i dążenie do wyłączności. Wymienione cechy mainstreamowego autorstwa dobrze ilustruje przypadek rozprawy sądowej z 2016 roku toczącej się między Sherrilyn Kenyon i Cassandrą Clare, której pozew został oparty na podobieństwie serii urban fantasy - Nocnych Łowców Clare do starszej serii z tego samego gatunku, jakim jest Mroczny Łowca Keyon. Jako podobieństwa wymieniono występowanie w obu powieściach elitarnego ugrupowania łowców, których zadaniem jest ochrona ludzi przed zagrożeniami z nadnaturalnego świata oraz głównej bohaterki, która po ocaleniu przez przystojnego łowcę, odkrywa, że jej zadaniem jest zabicie demonicznego ojca ${ }^{17}$. Nawet pobieżny przegląd współczesnej fantastyki ujawni, że jest to niezwykle rozpowszechniony schemat i że podobieństwa te mogą wypływać z aktualnej mody, trendu lansowanego przez wydawców czy wymagań czytelników. Spory o to, do kogo ten schemat należy, wydają się nie tylko bezprzedmiotowe, ale też bezcelowe. Widać tu wyraźnie, że chociaż fanowska produkcja kulturowa kopiuje mechanizmy twórczości popkulturowej, nadaje im przy tym inne znaczenia. W związku z tym pytanie o to, czy niekonkurencyjny wymiar produkcji fanowskiej wiąże się ze zbiorowym charakterem autorstwa, wydaje się nierozstrzygnięte, skoro na innym poziomie produkcji kulturowej zbiorowe autorstwo może zostać ujęte w ramy ekspensywnego, korporacyjnego prawa autorskiego. Nie ulega bowiem wątpliwości, że seryjna produkcja popularnych powieści stanowi rodzaj zbiorowego autorstwa zgodnie z modelem tzw. Harlequina, czyli chociażby w formie wypełniania schematu stworzonego przez wydawnictwo.

Wśród istotnych cech twórczości fanowskiej należałoby jeszcze wymienić bezpośredni charakter dystrybucji. Oznacza to, że twórca jest swoim własnym dystrybutorem, publikującym teksty fanowskie na wybranych stronach (Fanfiction.net, AO3, Wattpad, YouTube i inne, w tym blogi) w zależności od indywidualnych preferencji. W szerszym zakresie rolę dystrybutorów pełnią też inni fani, na przykład przez tworzenie list polecanych tekstów i dzielenie się linkami. Proces społecznej wymiany tekstów zachodzi tu bez pośredników w postaci rynku i jego instytucji, wydawców i redaktorów (tę ostatnią funkcję częściowo pełni beta). Udostępnianie własnych tekstów, czy też samopublikacja, ma dwa ciekawe efekty: egalitarność twórczości fanowskiej (każdy może publikować, formalne wymogi publikacji na danym portalu są łatwe do spełnienia) oraz pojawiający się dość często, brak dystansu autora względem tekstu. Ten ostatni

17 A. Flood, Sherrilyn Kenyon sues Cassandra Clare for »willfully copying «er Novels, "The Guardian" 10 lutego 2016, [online:] https://www.theguardian.com/books/2016/feb/10/sherrilyn-kenyon-sues-cassandra-clare-for-wilfully-copying-her-novels [data dostępu: 14.06.18]. 
przybiera różne formy: od braku umiejętności przyjmowania krytyki (chociażby na analizatorni) do nieudzielenia zgody na tłumaczenia.

Egalitarność kultury fanowskiej ma szczególnie znaczenie w przypadku roli twórczości fanowskiej, a zwłaszcza fanfiction jako czynnika konsolidującego społeczność fanowską. Poczucie, że autor (nawet Big Name Fan) jest „jednym z nas", współfanem, z którym można nawiązać kontakt, ma istotny wpływ na poczucie bliskości i solidarności w fandomach, co przekłada się na brak formalnej hierarchii wśród fanów w danej społeczności. Negatywną stroną tego zjawiska jest uzależnienie rozwoju twórczości fanowskiej od odbioru - ponieważ emocjonalna gratyfikacja to jedyna forma zapłaty, jej brak (w postaci komentarzy czy poczucia wsparcia ze strony współfanów) może zaowocować zaprzestaniem działalności, na przykład niedokończeniem fanfika, jeśli nakład pracy jest zbyt wielki w stosunku do zainteresowania, jakie wzbudza. Brak emocjonalnego dystansu względem tekstu, który cechuje część autorów w fandomie, jest tym ciekawszy, że w ramach produkcji kulturowej w tym obiegu autorstwo nie oznacza własności. Podkreśla to popularność disclaimer ${ }^{18}$, czyli noty autorskiej informującej, że autor fanfiction nie rości sobie praw do opisywanych postaci oraz światów i wskazuje popkulturowych producentów tekstu wyjściowego jako prawomocnych właścicieli. Brak dystansu autorów fanfiction wobec swoich tekstów uwidacznia się szczególnie w odpowiedzi na krytykę ze strony czytelników czy analizatorni, odbieraną jako atak na osobę autora, a nie tekst. Można również zauważyć, że w tym modelu produkcji autorstwo jako własność zostało zastąpienie autorstwem rozumianym jako afektywność, przywiązanie czy wręcz identyfikacja (zarówno z popkulturowym obiektem adoracji, jak i ze stworzonym na jego podstawie tekstem).

Ostatnią cechą fanowskiej produkcji kulturowej, o której warto wspomnieć, jest status tekstu fanowskiego jako dzieła w toku (work in progress, WIP), co wiąże się z jego funkcjonowaniem w ramach autorstwa zbiorowego. Tak jak każdy tekst popkulturowy jest niedokończony w tym sensie, że może zostać rozszerzony przez fanfiction, tak i każdy tekst fanowski pozostaje otwarty. I to pod dwoma względami. Po pierwsze, jako twórczość zależna, osadzona najczęściej w konkretnym świecie przedstawionym, jest otwarty w ten sposób, że nie wymaga precyzowania w tekście realiów miejsca akcji (odnosi się do tego wspominana wcześniej niesamodzielność tekstu fanfiction). Odbiorca bez trudu rozpoznaje świat przedstawiony dzięki znajomości tekstu wyjściowego albo na mocy konwencji i fanonu, jeśli dany tekst jest określonym AU. Po drugie, każdy tekst fanfiction może potencjalnie zostać rozszerzony o dalsze teksty albo ulec transformacjom w wyniku przeniesienia

18 Zob. A. Kobus, J. Krzyżanowska, Stownik fandomu i fanfiction dz. cyt. 
do innego medium (fanowskie „ekranizacje” fików w ramach viddingu i tym podobne). W przypadku kultury popularnej otwartość tekstu ma silnie komercyjny charakter, umożliwiający serializację i generowanie kolejnych zysków. W fanowskiej produkcji kulturowej tekst (popkultury i fanowski) funkcjonuje jako dobro wspólne umożliwiające dalszą produkcję, ogólnie dostępny rezerwuar kulturowego kapitału. Otwarcie tekstów odpowiada zbiorowemu modelowi autorstwa, jaki przekłada się na brak wyraźnych granic między tekstami, które zadłużone są wobec innych tekstów, uczestnicząc w nieustannym, intertekstualnym dialogu. Najczęściej wykazanie wszystkich nawiązań w danym tekście kanonicznych i fanonicznych, motywów zaczerpniętych z innych fików czy z rozwijającego się dyskursu fanowskiego $w$ internecie - pozostaje niemożliwe, ponieważ sami autorzy nie zawsze są świadomi, ile z ich lektur zostaje zawarte w tekstach. Można uznać tę cechę za charakterystyczny element twórczości jako takiej - tekst zawsze będzie mądrzejszy od swojego twórcy.

\section{Rewolucja autorstwa zbiorowego}

Identyfikując model autorstwa w fandomie jako zbiorowy i kooperacyjny oraz jego przełożenie na status tekstów jako otwartych i niemożliwych do odseparowania od siebie nawzajem, należy spytać, w jaki sposób model ten odnosi się do autorstwa w kulturze zachodniej czy też tego, co identyfikujemy jako dominujący model autorstwa w tejże kulturze. Autorstwo jako instytucja konstruowana przez krytykę literacką, teorię literatury, estetykę i praktyki rynkowe ma wyraźnie postromantyczny charakter, przede wszystkim w znaczeniu zakorzenienia w romantycznych kategoriach oryginalności ${ }^{19}$, celowości ${ }^{20} \mathrm{i}$ (auto)ekspresji,

19 Pojawienie się oryginalności jako istotnej kategorii estetycznej związanej z procesem twórczym w pierwszej połowie XVIII wieku (mniej więcej od 1718 roku, kiedy Johna Miltona zaczęto sławić za oryginalność właśnie) stanowi ciekawy zwrot w europejskiej refleksji na temat charakteru twórczości. Warto pamiętać, że przez dłuższy czas dominujący modelem twórczym było naśladowanie ustalonych reguł, a za oryginalność uważano ciekawą rekonstrukcję dostępnych elementów. Edward Young podsumował tę zmianę w dyskursie w swoich esejach. W On Lyric Poetry z 1728 roku pisał o pomniejszej roli naśladowania w procesie twórczym, a jego słynny list Propozycje dotyczace oryginalnej twórczości z 1759 roku ustanowił podwaliny romantycznej estetyki angielskiej, wprowadzając do dyskursu autorskiego figurę geniusza i bezpośrednie powiązanie oryginalnej twórczości z wyrazem osobowości autora. Innymi słowy - oryginalna twórczość stanowiła znak genialnej osobowości.

${ }^{20}$ Zagadnienie celowości procesu twórczego przekłada się głównie na przeświadczenie o braku przypadkowych czy niezamierzonych elementów w tekście kultury. Zostało oczywiście podważone przez XX-wieczne awangardy, przede wszystkim dadaistów z ich sztuką opartą na przypadkowości i losowości. Współcześnie niezwykle ciekawy jest wątek założonej celowości 
tworzących szczególną więź między autorem a tekstem, która odczytana zostaje jako własność - prawna i symboliczna ${ }^{21}$. W takim ujęciu autor funkcjonuje jako gwarancja sensu tekstu, ten, który sens (mniej lub bardziej) świadomie w tekście zakodowa ${ }^{22}$. Nawet ta pobieżna charakterystyka autorstwa ujawnia dwie istotne kwestie. Po pierwsze, autorstwo to wysoce wyspecjalizowane kulturowe narzędzie, sztuczny twór kulturowy bardziej skomplikowany niż proste przełożenie praktyki twórczej na dyskurs społeczny. Pomimo tego zachowane zostają pozory autorstwa jako instytucji „naturalnej” czy wręcz organicznie wynikającej z samego charakteru procesu twórczego. Po drugie, autorstwo w obrębie twórczości fanowskiej stanowi niemal całkowite przeciwieństwo dominującego modelu autorstwa. I chociaż postromantyczne rozumienie autorstwa zostało podważone przez liczne refleksje - marksistowską, ujmująca proces twórczy jako efekt działania zewnętrznych wobec autora sił społecznych i materialnych; psychoanalityczną, w ramach której proces twórczy to efekt działania niezgłębionych sił wewnętrznych; czy wreszcie koncepcję śmierci autora i intertekstualności - w dalszym ciągu stanowi dominującą siłę kształtującą proces produkcji kulturowejej. Dzieje się tak dlatego, że zachodnie autorstwo, ukształtowane na przełomie XVIII i XIX wieku, wraz z pojawieniem się i rozwojem prawa autorskiego i komercyjnego rynku kulturowego, jest instytucją rynkową. Powiązane z autorstwem kategorie estetyczne, takie jak oryginalność czy ekspresja, paradoksalnie służą parcelacji tekstów, ich separacji, przez co łatwiej mogą funkcjonować w obiegu rynkowym jako produkty. Autorstwo pełni więc rolę narzędzia, którego zadaniem jest zagwarantowanie klarowności materiału literackiego: separacji tekstów za pomocą kategorii oryginalności i funkcjonowania weryfikowalnej interpretacji, dla której punktem odniesienia staje się intencja autorska. Klarowność znaczeń i tekstów działa jako pochodna klarowności podmiotu autorskiego i przekłada się wprost na sprawne funkcjonowanie tekstów w ramach obecnego kształtu rynku ${ }^{24}$. Tak rozumiane autorstwo przedstawia proces twórczy jako czynność jednostkową, czy wręcz wyizolowaną, zgodnie z zaproponowaną przez Jacka Stillingera metafora „mitu samotnego geniusza” ${ }^{25}$. Andrew Bennet zwraca

procesu twórczego w kontekście funkcjonowania różnego rodzaju internetowych generatorów fabuł, wątków i postaci, które stanowią dostępne narzędzia pisarskie, pomocne przy tak zwanym bloku twórczym.

${ }^{21}$ Zob. M. Ross, Authors and Owners. The Invention of Copyright, Cambridge and London 1993.

22 A. Bennett, The Author, New York 2005, s. 8.

23 Tamże.

${ }^{24}$ Przywołane tu tezy stanowią skróconą wersję wywodu na temat ideologii autorstwa ze wspomnianej wcześniej rozprawy doktorskiej.

25 J. Stillinger, Multiple Authorship and the Myth of Solitary Genius, New York 1991, s. VI. 
uwagę na funkcjonujące przeświadczenie o jednostkowym charakterze procesu twórczego, pisząc, że:

autorska współpraca postrzegana jest jako wyjątek potwierdzający regułę samotnego autorstwa. W postromantycznym dyskursie krytycznym praca zbiorowa posiada niezdrowy posmak skandalu, postrzegana jest jako wstydliwy rodzinny sekret literatury, dzielona wada pisania [...] dlatego zakres współpracy nad danym tekstem jest zwykle bagatelizowany albo sprowadza się do dyskusji o tym, jak kooperacja dwóch kreatywnych umysłów wpływa na potencjalną wartość estetyczną pracy ${ }^{26}$.

Również Linda Brodkey zwraca uwagę na to, jak silnie zakorzeniony jest obraz samotnego aktu twórczego:

Ludzie piszą dla i do innych ludzi, ale jednak, kiedy myślimy o pisaniu, widzimy samotnego autora. Widzimy pisarza samotnego na poddaszu, pracującego nad ranem przy świetle świec. Przy zamkniętych okiennicach. Albo widzimy pisarza w dobrze wyposażonym gabinecie, z palcami na klawiszach maszyny do pisania albo klawiaturze komputera. Zasłony są zaciągnięte. Albo nawet widzimy pisarza pochylonego nad manuskryptem we wspaniałej publicznej lub uniwersyteckiej bibliotece, ściany i regały stojące pomiędzy nim a światem. Bez względu na to, czy scena pisania jest poetycka, czy prozaiczna, pisarz znajduje się ponad światem, na poddaszu, chwilowo uwolniony od rodzinnych i towarzyskich zobowiązań, w swojej pracowni, oddzielony od świata w bibliotece. Zawsze ten sam obraz - autor pracujący samotnie ${ }^{27}$.

Autorstwo zbiorowe, kooperatywne, współpraca autorska stanowią zagrożenie dla integralności tekstów. Znaczące jest, że także na poziomach produkcji kulturowej, gdzie zbiorowe autorstwo stanowi nieodzowną cechę powstania dzieł (ich finalizacja zależy od wielu czynników i pracy wielu osób), na przykład w produkcji filmowej, akcentuje się zazwyczaj rolę jednostkowego autora (reżysera, scenarzysty i tak dalej). Tłumaczy to także popularność autorskiej teorii kina, tym bardziej jeśli weźmie się pod uwagę jej nobilitującą funkcję w kreowaniu wizji kinematografii jako medium artystycznego.

Autorstwo zbiorowe bezpośrednio sprzeciwia się kategorii oryginalności jako opartej na ekspresji unikatowego „ja” autora, a więc twórczości jako autoekspresji. Ten wymiar współczesnego dyskursu autorstwa szczególnie widoczny jest w androcentrycznej teorii literatury Harolda Blooma, wyrażonej w metaforze „lęku

26 A. Bennett, dz. cyt., s. 95.

27 L. Brodkey, Academic Writing as Social Practice, New York 1987, s. 54-55. 
przed wpływem". Chociaż sam Bloom twierdzi, że jego teoria opisuje mechanizmy literackie, a nie psychiczne, trudno rozpatrywać ją w takim ujęciu, biorąc pod uwagę własne ugruntowanie w języku psychoanalizy oraz bezpośrednie odniesienia do kompleksu Edypa i lęku kastracyjnego ${ }^{28}$. W ujęciu Blooma proces twórczy ma charakter antagonistycznej relacji między autorami. Wpływ wartościowany jest w tym ujęciu jednoznacznie negatywnie - jako utrata oryginalności i tożsamości, twórczej (podmiotowej) autonomii ${ }^{29}$. Lęk przed zadłużeniem ujawnia w pełni konkurencyjny wymiar współczesnego dyskursu autorskiego. Proces produkcji kulturowej traktowany jest tutaj jako wyścig po pierwszeństwo, bezwzględna walka o uznanie i zawłaszczenie danego motywu czy wykonania. I chociaż Bloom ujawnia, że każda twórczość ma charakter zależny - poprzez uwikłanie twórczych jednostek w kulturę, historię i język - zależność ta jest jedynie źródłem antagonizmów i kompleksów, które należy w swojej twórczości przepracować. Nie jest to ujęcie oryginalności jako twórczej rekonstrukcji, ale jako wieloetapowego procesu niwelacji wpływu, którego celem jest ustanowienie poety (twórcy) swoim własnym źródłem, odzyskanie zagrożonej autonomii ${ }^{30}$.

Jak łatwo zauważyć, twórczość fanowska nie cierpi na lęk przed wpływem. Wprost przeciwnie - funkcjonując jako twórczość zależna, akceptuje nieuchronny wpływ materiału wyjściowego oraz wpływ własnego obiegu kulturowego (fanonu). Co więcej, samą twórczość fanowską można traktować jako pragnienie wywarcia wpływu, pozostawienia jednostkowego śladu na popkulturowym przedmiocie fanowskiego afektu. Łączy się to z jej niekonkurencyjnym charakterem: wpływ w twórczości fanowskiej nie zagraża ani pozycji twórcy, ani tekstu. Działalność ta operuje w modelu autorstwa zbiorowego i skrajnej intertekstualności, która rezygnuje z autonomii tekstu, a przez to - z separacji poszczególnych tekstów względem siebie. Autonomia zostaje umniejszona na rzecz produktywności, łatwo bowiem zauważyć, że wewnętrzna różnorodność tekstów fanowskich oraz ich liczebność znacząco przewyższa różnorodność tekstów popkulturowych.

Podsumowując zawarte tu rozważania, chciałabym zaproponować ujęcie fanowskiego modelu autorstwa jako alternatywnego czy wręcz opozycyjnego wobec dominującego postromantycznego dyskursu autorstwa. Chociaż ten ostatni pojawia się w fanowskiej refleksji, chociażby w formie nastawienia wobec autora/ów popkulturowego tekstu wyjściowego, nie rzutuje na same praktyki

${ }^{28}$ H. Bloom, Lęk przed wptywem. Teoria poezji, tłum. A. Bielik-Robson, M. Szuster, Kraków 2002, s. 20.

29 Tamże, s. 21.

30 Tamże., s. 54-59. 
twórcze w fandomach. Uważam, że model twórczości fanowskiej bliższy jest praktyce twórczej niż obowiązujący model postromantyczny, co wynikać może z nierynkowego charakteru produkcji kulturowej w fandomach. W tym sensie produkcja fanowska oddaje właściwe cechy procesu twórczego, zbiorowy i intertekstualny charakter wszelkiej twórczości, wynikający z samej struktury języka jako ponadjednostkowego i ograniczonego.

W dobie ekspansywnego prawa autorskiego oraz kurczącego się zakresu domeny publicznej ${ }^{31}$ i dozwolonego użytku, fanowskie praktyki autorskie stanowią rewolucyjne narzędzie do określania alternatywnych modeli powstawania i obiegu tekstów kultury. Należy zauważyć, że dominacja postromantycznego modelu autorstwa doprowadziła do delegalizacji różnych form twórczości właśnie w imię obrony prawa autorskiego. Pugh we wspomnianej wcześniej pracy opisuje sytuację, w której zjawiska i gatunki charakterystyczne współcześnie dla twórczości fanowskiej - prequle, sequele, retellingi, zmiany zakończenia i tak dalej - stanowiły część powszechnie dostępnych zabiegów w ramach produkcji kulturowej. Rozwój komercyjnego rynku ograniczył jednak zakres dostępnych form ekspresji, przede wszystkim za sprawą cezury czasowej okresu prawnej ochrony. Arbitralnie także wyznaczono legalnie dostępne formy twórczości zależnej w postaci parodii, pastiszu i karykatury, ale już nie kontynuacji, alternatywnych zakończeń czy prequeli. Zupełnie jakby istniała strukturalna lub jakakolwiek inna obiektywna różnica między różnymi formami twórczości transformatywnej. Delegalizacja pewnych form twórczości przez ich wykluczenie z obiegu komercyjnego nie jest jednak jedynym aktem ekspansji ze strony prawa autorskiego. Także niekomercyjna twórczość fanowska, mieszcząca się w dozwolonym użytku, podlega nieustannym atakom ze strony producentów popkultury. Wśród aktualnych zagrożeń wymienić można propozycję obligatoryjnego systemu filtrowania zawartości na stronach i portalach publikujących treści kreowane przez użytkowników (do których zalicza się YouTube, AO3 i Fanfiction.net). Celem filtrowania byłoby oczywiście blokowanie i usuwanie wszelkich treści posługujących się materiałem objętym ochroną prawną, bez względu na to, czy mieszczą się w zakresie dozwolonego użytku. Uwidacznia to, do jakiego stopnia aktualny kształt rynku i lobby na rzecz ekspansywnego prawa autorskiego nieprzychylne jest kulturze fanowskiej.

Model autorstwa w twórczości fanowskiej dostarcza narzędzia pozwalające na krytykę i przeformułowanie obowiązującego modelu autorstwa i związanego

31 W 2018 roku domena publiczna w Stanach Zjednoczonych nie została wzbogacana o ani jeden nowy tekst i ten stan rzeczy utrzymuje się od 20 lat w związku z przyjęciem retroaktywnej uchwały o przedłużeniu ochrony prawnej z 1998 roku. 
z nim ograniczenia produkcji kulturowej w wyniku delegalizacji pewnych form twórczości. Znaczące jest, że żadna dotychczasowa dekonstrukcja autorstwa, łącznie z nośną koncepcją śmierci autora, nie wpłynęła w większym stopniu na kształt rynku literackiego jako podstawowej instytucji wspierającej obecny kształt autorstwa. Stillinger zauważa wręcz, że śmierć autora to konserwatywna idea wspierająca postromantyczny dyskurs autorstwa w jego micie samotnej twórczości ${ }^{32}$. W tym sensie polityczny, subwersywny potencjał kultury fanowskiej kryje się nie tylko w proponowanych przez nią treściach czy w krytyce społecznej w ramach dyskursu fanowskiego, lecz także w samych strukturach w jej funkcjonowania, w praktykach twórczości fanowskiej. Działalność artystyczna fanów pokazuje, że postromantyczny model autorstwa nie jest ani jedynym, ani naturalnym modelem strukturowania autorstwa, że istnieją sposoby myślenia o autorstwie znacznie bardziej zbliżone do rzeczywistego charakteru procesu twórczego oraz że sprawdzają się one w praktycznym wymiarze produkcji kulturowej.

\section{Bibliografia}

1. S. Ahmed, Differences That Matter. Feminist Theory and Postmodernism, New York 2004.

2. A. Bennett, The Author, New York 2005.

3. H. Bloom, Lęk przed wptywem. Teoria poezji, tłum. A. Bielik-Robson, M. Szuster, Kraków 2002.

4. L. Brodkey, Academic Writing as Social Practice, New York 1987.

5. A. Flood, Sherrilyn Kenyon sues Cassandra Clare for »willfully copying "her novels, “The Guardian” 10 lutego 2016, [dostęp online:] https://www.theguardian.com/ books/2016/feb/10/sherrilyn-kenyon-sues-cassandra-clare-for-wilfully-copying-her-novels [data dostępu: 14.06.18].

6. M. Foucault, Kim jest autor?, [w:] tegoż, Powiedziane, napisane. Szaleństwo i literatura, tłum. B. Banasiak, Warszawa 1999.

7. K. Kielos, Jedyna płeć. O tym, dlaczego prześladuje cię homo oeconomicus i jak niszczy twoje życie, nie mówiq̨c już o światowej gospodarce, Warszawa 2014.

8. A. Kobus, Burzenie czwartej ściany. Strategie budowania relacji twórców popkultury z fankami, [w:] Seriale w kontekście kulturowym. Widzowie-fani-twórcy, pod red. A. Krawczyk-Łaskarzewska, A. Naruszewicz-Duchlińska, Olsztyn 2016.

9. A. Kobus, J. Krzyżanowska, Stownik fandomu i fanfiction, [w:] Netlor. Wiedza cyfrowych tubylców, pod red. P. Grochowskiego, Torun 2012.

${ }^{32}$ J. Stillinger, dz. cyt., s. VI. 
10. B. Kulesza-Gulczyńska, Czym różni się autor od aŁtora, czyli fanowskie z autorstwem, „Tekstualia” 2015, nr 2 (41).

11. J. Litman, The Public Domain, [w:] „Emoty Law Journal” 1990, nr 4 (39).

12. S. Pugh, The Demoratic Genre. Fan Fiction in a Literary Contex, Glasgow 2005.

13. M. Ross, Authors and Owners. The Invention of Copyright, Cambridge and London 1993.

14. J. Stillinger, Multiple Authorship and the Myth of Solitary Genius, New York 1991.

15. M. Tymińska, A. Włodarczyk, Fan Fiction a literacka rewolucja fanowska. Próba charakterystyki zjawiska w następujacy sposób, „Panoprikum” 2012, nr 11 (18).

Summary: The present article analyses contemporary approaches to authorship in fandom studies, focusing on authorship in the context of fanworks. It recognises the collaborative and intertextual dimension of fan authorship, which may be perceived as an alternative to the dominant commercial model of authorship, depicted as the work performed by a lone creator, labouring to create a unique text. Consequently, this model undermines the dominant position of thus construed notion of authorship. In addition, such an approach reveals the subversive potential of fanworks as enabling a re-formulation of post-Romantic notion of authorship (and thus potentially leads to a re-interpretation of the resultant expansiveness of intellectual copyright).

Key words: autorstwo, autor, produkcja kulturowa, fanfiction, prawo autorskie, twórczość zależna, twórczość transformacyjna 